Mini Review

\title{
Blood transportation using multi-vehicle systems; optimal blood transport temperature in terms of hemolysis
}

\begin{abstract}
Recently, the use of drones has been proposed for blood transportation. Therefore, in this review, we first detailed the history of blood storage and transportation for red blood cell transfusion, and then presented ideas for creating rules to improve the safety of blood transportation, based on the idea that hemolysis is the problem for blood quality. In particular, it touches on the current logistics of blood transportation in which public transportation is not used, including the recent use of drones to transport blood, and points out the problems with this system. We discuss how instances of improper red blood cell transportation with inadequate temperature control are still observed, and that temperature control, vibration remain the major hindrances to appropriate blood transportation. Therefore, a set of rules that will contribute to appropriate and rapid blood transportation is warranted. Moreover, there are notable differences in blood storage rule between Japan and the US and UK, and there is no legal transportation rule in Japan. Based on our review and experience, we think that basic temperature control at $2-6^{\circ} \mathrm{C}$ should always be maintained to prevent blood deterioration even if unmanned aerial vehicle (drone) technologies are available.
\end{abstract}

Keywords: transfusion, blood transportation, temperature, drone, helicopter, rules
Volume 9 Issue I - 202I

\author{
Fumiatsu Yakushiji, ${ }^{1,2}$ Koki Yakushiji, ${ }^{3}$ Mikio \\ Murata, ${ }^{4}$ Naoki Hiroi, ${ }^{5}$ Hiroshi Fujita ${ }^{6}$ \\ 'Department of Internal Medicine, Tokyo Metropolitan Bokutoh \\ Hospital, Japan \\ ${ }^{2}$ Faculty of Medicine, Toho University, Japan \\ ${ }^{3}$ Graduate School of Media and Governance, Keio University, \\ Japan \\ ${ }^{4}$ Department of Clinical Pharmacy, Yokohama University of \\ Pharmacy, Japan \\ ${ }^{5}$ Center of Medical Education, Faculty of Medicine, Toho \\ University, Japan \\ ${ }^{6}$ Department of Transfusion Medicine, Tokyo Metropolitan \\ Bokutoh Hospital, Japan
}

Correspondence: Fumiatsu Yakushiji, MD, PhD, Department of Internal Medicine, Tokyo Metropolitan Bokutoh Hospital, 4-23I5 Koutoubashi Sumida, Tokyo I30-8575, Japan, Tel +8I-3-36336I5I, Fax8I-3-3633-6I73,Email clini@nifty.com

Received: January |2, 2021 | Published: February |5, 202 |
Abbreviations: AABB, american association of blood banks; DBDF, donated blood distribution foundation; FDA, food and drug administration; HEMS, helicopter emergency medical service; ISBT, international society of blood transfusion; JRC, japanese red cross society; LD, lactate dehydrogenase; MHLW, ministry of health, labour and welfare in japan; WHO, world health organization

\section{Current status of blood transport in Japan}

As evidenced by the Great East Japan Earthquake, Japan is a country prone to natural disasters. It is no exaggeration to say that the anticipated Nankai Trough earthquake could lead to another major disaster in the country. Transportation of blood during natural disasters is crucial. However, the Japanese procedures for the stable transportation of blood for transfusion can even be disrupted by cliff falls that cause interruptions in transportation.

Furthermore, in certain areas, due to the current COVID-19 pandemic, it has become increasingly difficult to transport surgical patients in need of a blood transfusion. In such cases, air transportation of blood is necessary. In addition, there is a growing need for blood transport by land, air, and sea in cases where transport by land is not possible, such as road obstacles during blood transport due to heavy snowfall or earthquakes, or transport to remote islands.

In Japan, nearly all routine blood transportation by automobiles occurs through an established network. ${ }^{1,2}$ However, the quality of blood transportation is not always guaranteed for emergency medical services and medical services during disasters, such as those mentioned above. Moreover, in remote islands, transportation is difficult even during normal times.
Recently, the use of drones has been proposed for blood transportation, but rules need to be established to ensure safety. Currently, we are preparing to use drones for blood transportation during actual operations and also for blood transportation to new areas. Occasionally, in drone trials, inappropriate red blood cell transportation with inadequate temperature control and other problems is observed. Rules that govern both flight and quality assurance during the actual transportation of blood are warranted. In this review, we will focus on the storage and transportation of blood.

Currently, the blood supply in Japan is monopolized by the Japanese Red Cross Society (JRC), which transports over approximately 1,300,000 liters of blood. ${ }^{1}$ Usually, after blood donation and storage, blood supply services come under the direct control of the JRC, although in the Tokyo area, the blood is supplied by the Donated Blood Distribution Foundation (DBDF). ${ }^{2}$ In terms of the geographic scope of the blood supply in Japan, the JRC is clearly a larger supplier, but considering the blood supply in the Tokyo area, the DBDF is responsible for more than $10 \%$ of the blood supply in Japan.

In any case, the current supply of blood, especially in areas where traffic does not cause hindrances, is transported by automobiles from JRC blood centers. During the transportation of blood supplied by the JRC, blood temperature, an important parameter for maintaining blood quality, is controlled using the cooling material Constar II (Daido Industries Inc., Osaka, Japan). For blood supplied by the DBDF, blood temperature is controlled using an RBC cooler Type III (JSP Co., Ltd. Tokyo, Japan). Normally, the blood temperature is strictly controlled between $2^{\circ} \mathrm{C}$ and $6^{\circ} \mathrm{C}$ using the above method.

Both the JRC and DBDF supply blood to areas wherein blood supply is difficult, such as remote islands. Therefore, in addition to 
regular car transportation, a wide variety of transportation methods may be used. Naturally, in the event of a disaster, when all medical resources in the country - including blood - are mobilized, complicated transportation methods will likely be used. However, even in such cases, it is necessary to try to maintain the quality of blood as best as possible.

\section{History of blood storage and transport}

In this review, we outline the current status of blood transportation carried out using cars, trains, ships, airplanes, multicopters, and helicopters. We further discuss the history of blood transportation in the current context, the conditions necessary for actual blood transportation, and the methods required for implementation. The conditions necessary for blood transportation were obtained from a literature search, whereas the evaluations for some vehicles not examined in the literature were based on values of lactate dehydrogenase (LD) obtained from unpublished data of previous studies.

The results, including the key points of each paper and the outcomes of the self-test, are summarized in Table 1. Mechanical shaking and long-distance transport of stored blood in Japan was first investigated by Kato et al. in 1957, as described in Table 1. In their study, they found that when long-distance transportation of whole blood was performed (round-trip distance of $\sim 1,100 \mathrm{~km}$ between Tokyo and Osaka and approximately $30 \mathrm{~km}$ distance of transport by car or foot) at a temperature of $4-6^{\circ} \mathrm{C}$, no blood deterioration occurred. ${ }^{3}$

The first official guidelines for the storage of red blood cell solutions in Japan were provided by the Manual for the Storage and Management of Blood Products, which was published by the Pharmaceutical Affairs Bureau of the former Ministry of Health and Welfare in 1993. The storage temperature recommended was $4-6^{\circ} \mathrm{C}$, and this information is available on the current website of the Ministry of Health, Labor and Welfare (MHLW) ${ }^{4}$ The World Health Organization (WHO) published the Blood Cold Chain from Blood Donation to Transfusion protocol in 2002, which considers transfusion medicine as an essential part of modern health care. The framework provided therein is followed to this day. ${ }^{5}$

Table 1 also shows the results of a 2003 study examining 16-hour red blood cell storage in conditions of external temperatures ranging from $8^{\circ} \mathrm{C}$ to $35^{\circ} \mathrm{C}$ and blood transportation at allowable temperatures of $2-10^{\circ} \mathrm{C}$. The results of supercooling when the environmental temperature is high at $35^{\circ} \mathrm{C}$ can be observed. ${ }^{6}$ The results of the biochemical tests were not clear, and therefore, the quality status could not be determined.

Table I History of Blood Storage and Transport

\begin{tabular}{|c|c|c|c|c|}
\hline No & Vehicle, distance (km) & Temperature $\left({ }^{\circ} \mathrm{C}\right)$ & $\begin{array}{l}\text { Evaluation hematology, } \\
\text { biochemistry, etc. }\end{array}$ & References \\
\hline \multirow[t]{2}{*}{ \#I } & Automobile, over I, I00 & $4-6$ & $\begin{array}{l}\text { No significant difference in } \mathrm{RBC} \text {, } \\
\text { plasma hemoglobin levels, } \mathrm{Na} \\
\text { and } \mathrm{K} \text {. }\end{array}$ & Kato $\mathrm{K}$ et al. ${ }^{3}$ \\
\hline & Stored in the laboratory & & $\begin{array}{l}\text { Rotation and pendulum motion } \\
\text { caused changes in } \mathrm{Hb}, \mathrm{Na} \text { and } \mathrm{K} \\
\text { showed little change with intense } \\
\text { shaking. }\end{array}$ & \\
\hline$\# 2$ & Stored in the laboratory & $2-10$ & $\begin{array}{l}\text { None. Only temperature was } \\
\text { maintained. }\end{array}$ & Sharly PH et al. ${ }^{6}$ \\
\hline & & & $\begin{array}{l}\text { A significant increase in plasma } \mathrm{Hb} \\
\text { levels occurred in } 7 \text { days; however, }\end{array}$ & \\
\hline \#3 & Stored in the laboratory & 4 & $\begin{array}{l}\text { RBCs did not exceed the } 0.8 \% \\
\text { hemolysis threshold on day } 28 \text { of } \\
\text { storage. }\end{array}$ & Sawant RB et al. ${ }^{7}$ \\
\hline \multirow[t]{4}{*}{$\# 4$} & Automobile, over I,I00 & $3.9-4.1$ & $\begin{array}{l}\text { Twenty-three shock events; there } \\
\text { were indications of effects of } \\
\text { vibration and other effects. }\end{array}$ & Klose T et al. ${ }^{9}$ \\
\hline & Stored in the laboratory & $1-10$ & $\begin{array}{l}\text { It was intended to be stored } \\
\text { under the temperature conditions } \\
\text { shown on the left, with a stable } \\
\text { time of about } 20 \mathrm{~h} \text { at } 2-6^{\circ} \mathrm{C} \text {. }\end{array}$ & \\
\hline & Temperature Management & $2-6$ & & \\
\hline & $\begin{array}{l}\text { Below atmospheric air } \\
\text { pressure }\end{array}$ & $2-10$ & $\begin{array}{l}\text { Low pressures of less than } 200 \\
\text { mbar will cause unacceptable } \\
\text { hemolysis. }\end{array}$ & \\
\hline$\# 5$ & Helicopter (HEMS) & $1-6$ & $\begin{array}{l}\text { According to } 95 \% \text { confidence } \\
\text { intervals, temperatures of } 1-6^{\circ} \mathrm{C} \\
\text { were maintained. However, in } \\
\text { the summer, in } 8 \% \text { of cases, the } \\
\text { temperature was over } 6^{\circ} \mathrm{C} \text {. } \\
\text { Moreover, in winter cases, over } \\
15 \% \text { of cases had temperatures } \\
\text { below } 1{ }^{\circ} \mathrm{C} \text {. }\end{array}$ & Stein $C$ et al. ${ }^{18}$ \\
\hline
\end{tabular}


Table continued...

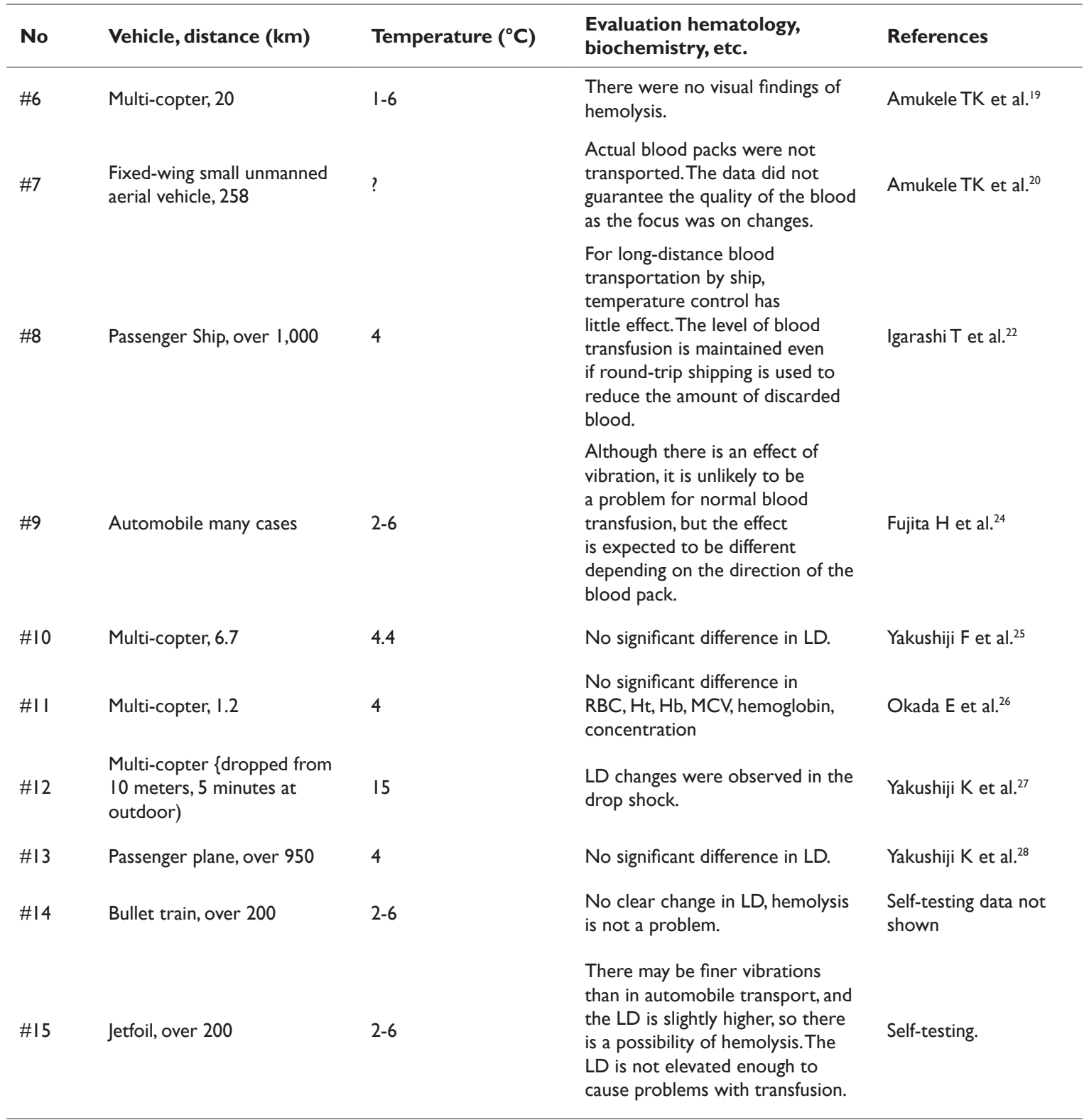

The results of an investigation by Sawant et al. ${ }^{7}$ in 2007 can also be seen in Table 1. Sawant et al. evaluated blood storage and hemolysis using macroscopic observations, free hemoglobin, and LD. They reported that the level of free hemoglobin initially increased during blood storage, with marginal hemolysis, and after 28 days of storage, gross hemolysis was observed, while LD and $\mathrm{K}$ showed a clear increase. However, the hemolysis rate reported by them was lower than the prescribed rate of $0.8 \%$. In addition, they summarized the importance of hemolysis in blood degradation and the 28-day period of storage. ${ }^{7}$ Interestingly, in 2008, based on WHO's blood cold chain protocol, Hardwick suggested that $2-6^{\circ} \mathrm{C}$ was ideal for the storage and transportation of red blood cells, although the role of vibration was not discussed. ${ }^{8}$

The blood storage protocol used by the German Armed Forces Blood Service in Koblenz kept temperatures between $2^{\circ} \mathrm{C}$ and $6^{\circ} \mathrm{C}$, as required by European guidelines, for at least 36 hours. Temperatures between $1{ }^{\circ} \mathrm{C}$ and $10^{\circ} \mathrm{C}$ were required by German guidelines for at least 48 or 64 hours at ambient temperatures between $-10^{\circ} \mathrm{C}$ and $40^{\circ} \mathrm{C}$. These were tested in the laboratory. In the field test, after 56 days of land transport at a distance of $1100 \mathrm{~km}$, there was a drop in ATP levels and twice as much hemolysis as in static blood. In 2010, preliminary results indicated that additional factors such as air pressure fluctuations and vibrations needed to be taken into account while designing blood transportation strategies. ${ }^{9}$

In 2012, Lee et al. conducted a review on temperature control. They referred positively to the rules of storage in the US, which were required by the Food and Drug Administration (FDA) ${ }^{10}$ and the American Association of Blood Banks (AABB $)^{11}: 1-6^{\circ} \mathrm{C}$ for $35-43$ days and transportation at $1-10^{\circ} \mathrm{C}$ for a short period of time for surgical use. ${ }^{12}$

This rule has since been changed to, "Blood that is transported from the collecting facility to the processing facility shall be 
transported in an environment capable of continuously cooling the blood toward a temperature range of $1-10^{\circ} \mathrm{C}$ or at a temperature as close as possible to $20-24^{\circ} \mathrm{C}$ for a period not exceeding 6 hours. Blood transported from the storage facility shall be placed in an appropriate environment to maintain a temperature range between $1{ }^{\circ} \mathrm{C}$ and $10^{\circ} \mathrm{C}$ during shipment." and "Storage should be ensured immediately after processing, and the red blood cells shall be placed in storage and maintained at a temperature between $1^{\circ} \mathrm{C}$ and $6^{\circ} \mathrm{C}$ "..$^{13}$

In 2013, for blood transportation in the UK, the guidelines stated that the components may be stored for a maximum of 35 days at a core temperature of $4 \pm 2^{\circ} \mathrm{C}$ if an adenine-supplemented anticoagulant was used; otherwise, the maximum storage period was 28 days at a core temperature of $4 \pm 2^{\circ} \mathrm{C}$. For transportation between the blood supplier and hospital, an upper limit of $10^{\circ} \mathrm{C}$ surface temperature was considered acceptable, but this was limited to one occasion not exceeding 12 hours. ${ }^{14}$ The latest guidelines on the transport of components from blood establishments to hospital blood banks/users, called the Guidelines for the Blood Transfusion Services by Joint United Kingdom (UK) Blood Transfusion and Tissue Transplantation Services Professional Advisory Committee (JPAC), state that "Transport time should be kept to a minimum. It should be noted that, occasionally, red cell components are issued before they have been cooled to their storage temperature $\left(4 \pm 2^{\circ} \mathrm{C}\right)$. In such circumstances, it may be neither possible nor necessary to maintain the transport temperature within the range of $2-10^{\circ} \mathrm{C}$ and personal judgment should be exercised". ${ }^{15}$

In 2014, the Yamagata Prefecture Joint Committee on Blood Transfusion Therapy in Japan issued a draft plan for the storage and transport of blood at $2-6^{\circ} \mathrm{C} .{ }^{16}$ In 2015 , the MHLW of Japan announced that the storage of red blood cell products should be done at $2-6^{\circ} \mathrm{C}$ (Biological Agents Standard, Ministry of Health, Labor and Welfare Notification No. 192, 2015), and this remains the current standard. ${ }^{17}$

Based on the studies listed above, it can be concluded that blood was predominantly transported by automobiles at a temperature range of $1-10^{\circ} \mathrm{C}$ or $2-6^{\circ} \mathrm{C}$. However, the effects of vibration, which could be an important factor, were not considered. In addition, although maritime transportation is used in actual operations, there are no research reports on temperature control during maritime transportation.

A report was published on the temperature of blood transported by an emergency helicopter from the helicopter emergency medical service (HEMS) in 2016. According to $95 \%$ confidence intervals, temperatures of $1-6^{\circ} \mathrm{C}$ were maintained. However, in the summer, in $8 \%$ of cases, the temperature was over $6^{\circ} \mathrm{C}$. Moreover, in winter cases, over $15 \%$ of cases had temperatures below $1^{\circ} \mathrm{C}$. Together, these indicated the difficulties in temperature maintenance. ${ }^{18}$

In 2017, Amukele et al. ${ }^{19}$ from Johns Hopkins University began transporting blood by multicopters ${ }^{19}$ and fixed-wing small unmanned aerial vehicles. ${ }^{20}$ The flights were long-distance, spanning $258 \mathrm{~km}$, but actual blood packs were not used in their study. Therefore, the data did not reflect the impact of drone transport on the quality of blood.

Drone blood transportation is being adopted in actual practice, and operations begun in Africa in 2018. ${ }^{21}$ Igarashi et al..$^{22}$ began transporting blood by sea in Japan over a distance of $1,000 \mathrm{~km}$ to Ogasawara Island. They achieved storage temperatures of $2-6^{\circ} \mathrm{C}$ and established long-distance transport by ship. It was also found that the blood did not undergo hemolysis, most likely due to the temperature control. ${ }^{22}$

When considering the conditions necessary for blood transportation, it is important to remember that based on the International Society of Blood Transfusion proposal, Tocchetti et al. summarized that the temperature should be $2-6^{\circ} \mathrm{C}$, and it must not be below $1{ }^{\circ} \mathrm{C} .3^{23}$ Temperature control is mandatory, as described above. In addition to temperature, Fujita et al. studied the effect of vibration on blood using a temperature-controlled refrigerator placed in a car during blood transportation. ${ }^{24}$

Yakushiji et al. ${ }^{25}$ conducted a trial for strict temperature control in a drone, but the load weight required for transporting blood in a refrigerator at $2-6^{\circ} \mathrm{C}$ was too high for transport over long distances. ${ }^{25}$ Okada et al. also used a multicopter to transport a refrigerator that allowed temperature control. They performed hematological tests such as those for red blood cell count, hematocrit level, and hemoglobin concentration. However, the data was not included in the publication. ${ }^{26}$ Moreover, some reports also suggest that there may be safety issues with the fixed-wing drones used in actual practice in Africa, since blood is dropped from the drone to its final destination. ${ }^{27}$

Additionally, it has been reported that blood transported by commercial aircrafts in a temperature-controlled refrigerator does not get degraded, and the vibration during transport is clearly less than that during transport by automobiles. ${ }^{28}$ Furthermore, using LD-based assessments, bullet trains and Jetfoils (high-speed vessel) have also been examined for their feasibility of use in blood transportation..$^{25,27,28}$ For the remaining vehicles, our suggestions are made based on previously unpublished LD-based data.

Appropriate temperature and additional controls in blood transportation and reduction of blood wastage

On the basis of previous studies, the most important aspect during blood transportation is temperature, followed by vibration. The German military has also reported possible effects of atmospheric pressure on blood transportation at high altitudes, and this may need to be taken into consideration. ${ }^{9}$

In terms of temperature, a temperature of $2-6^{\circ} \mathrm{C}$ is optimum. For urgent surgical blood needs, however, leniency in loose controls may be acceptable. However, despite the effective use of blood, it is difficult to avoid blood wastage. ${ }^{29}$ This has been observed in the Tokyo neighborhood. Blood stored for emergencies such as bleeding during childbirth is often not used and may be discarded..$^{30}$ To prevent such wastage, it is hoped that the blood can be returned to JRC, close to the expiry date, for use at a medical center where there is a consistent demand for blood. For such a case, we consider following the blood transportation method of Igarashi et al would be effective. They used a stable refrigerator $\left(2-6^{\circ} \mathrm{C}\right)$ to transport blood from remote islands that are more than $1,000 \mathrm{~km}$ away from Tokyo to Tokyo before the expiration date so that the blood, in good condition, can be used and wastage is avoided. ${ }^{22}$ Therefore, it is safe to say that blood should be stored and transported at temperatures between $2^{\circ} \mathrm{C}$ and $6^{\circ} \mathrm{C}$ as far as possible.

In terms of vibration, the effects of long-distance transportation by land have been examined by the German Army ${ }^{9}$ and by Kato et al. ${ }^{3}$ In terms of ship transportation, transportation to Ogasawara island ${ }^{22}$ was studied for long distance blood transportation, and for short distance transportation, vibration experiments with jetfoils were conducted in Tokyo and Ooshima island (data not shown). Yakushiji et al. showed that the vibrations generated on passenger planes were less than those for land transportation modes and other modes of transportation. ${ }^{28}$ Fewer vibrations were recorded in drones than in other modes of transportation. (data not shown). 


\section{Discussion: a proposal temperature for blood transport to learn from history}

Based on experimental data and other results, official declarations have been made regarding the storage and transport of blood in various countries. The parameters for blood transportation in Japan, the UK, and the US are summarized in Table 2. The International Society for Blood Transfusion has recommended adopting a temperature range of $2-6^{\circ} \mathrm{C}$ as a general rule, and $1^{\circ} \mathrm{C}$ as the lowest permissible limit, but this has not been made a rule in each country.

Table 2 Proposal on storage and transport temperature for RBC

\begin{tabular}{llll}
\hline Organization & Region & Stored & Transport \\
\hline $\mathrm{MHW}^{17}$ & Japan & $2-6^{\circ} \mathrm{C}$ & - \\
$\mathrm{JPAC}^{15}$ & United Kingdom & $4{ }^{\circ} \mathrm{C} \pm 2^{\circ} \mathrm{C}$ & $2-10^{\circ} \mathrm{C}$ \\
$\mathrm{FAD}^{13}$ & United States of America & $1-6^{\circ} \mathrm{C}$ & $1-10^{\circ} \mathrm{C}$ \\
ISBT $2020^{23}$ & Worldwide & $2-6^{\circ} \mathrm{C}$ Must not go below $1^{\circ} \mathrm{C}$ & $2-10^{\circ} \mathrm{C}$ Maximum transit time 24 hours
\end{tabular}

MHLW, ministry of health, Labour and Welfare in Japan; JPAC, joint united kingdom (uk) blood transfusion and tissue transplantation services; FDA, food and drug administration; ISBT, international society of blood transfusion

In terms of transportation, there is no clear rule in Japan, but the UK, US, and ISBT 2000 have time limits of $2-10^{\circ} \mathrm{C}, 1-10^{\circ} \mathrm{C}$, and $2-10^{\circ} \mathrm{C}$, respectively. Although it has not been published yet, it is worth mentioning here that we observed blood deterioration at almost $0^{\circ} \mathrm{C}$ in our most recent experiment. In contrast, no deterioration of blood was observed when the temperature outside was $-7^{\circ} \mathrm{C}$, if the temperature of blood was adjusted between $2^{\circ} \mathrm{C}$ and $6^{\circ} \mathrm{C}$ by the blood transport device. Further, it is clear that blood is in a better condition between $2^{\circ} \mathrm{C}$ and $6^{\circ} \mathrm{C}$ than at $1{ }^{\circ} \mathrm{C}$ or lower than $10^{\circ} \mathrm{C}$, and this is the temperature range that we recommend.

If blood is stored and transported at an appropriate temperature, it may increase the chances of its use and reduce blood wastage prior to the expiration date. This can be extended to any means of transportation, as long as the temperature is controlled, as in the case of Ogasawara, where blood was transported by ship [22]. Moreover, it was found that vibrations, at least on drone flights and on ships, do not cause blood deterioration. However, fine vibrations, especially those on a jetfoil, can cause blood degradation. Another aspect to be considered is the 30-minute rule. When handling blood, it is sometimes impossible to maintain temperatures between $2^{\circ} \mathrm{C}$ and $6^{\circ} \mathrm{C}$ [31]. Although not recommended during real-time transport, in such cases we believe that applying the 30-minute rule rather than inappropriate handling, that is, handling blood at $6-10^{\circ} \mathrm{C}$, is easier.

\section{Conclusion}

Even with the use of temperature control equipment, it is desirable to maintain a temperature of $2-6^{\circ} \mathrm{C}$. The $2^{\circ} \mathrm{C}$ to $6^{\circ} \mathrm{C}$ rule should also be adhered to for blood transportation by drone. Except for when the environmental temperature is below $2^{\circ} \mathrm{C}$, it could be argued that the 30-minute rule, where the temperature of blood cannot be maintained between $2^{\circ} \mathrm{C}$ and $6^{\circ} \mathrm{C}$, applies to drone transport. In spite of the availability of innovative technologies like drones, the $2^{\circ} \mathrm{C}$ to $6^{\circ} \mathrm{C}$ rule should still be followed, which will reduce the amount blood wastage. Especially in Japan, the rules for temperature during blood transport have not yet been decided. Even on a global scale, shouldn't it be recommended that blood be maintained between $2^{\circ} \mathrm{C}$ and $6^{\circ} \mathrm{C}$ during transportation?

To summarize as follows,

a. Temperature control for blood transfusion transportation is not standardized

b. For blood transport, temperature maintenance at $2-6^{\circ} \mathrm{C}$ is required c. Drones transportation should also maintain temperature between $2-6^{\circ} \mathrm{C}$

\section{Acknowledgments}

We would like to thank Editage for English language editing.

\section{Conflicts of interest}

The authors declare no conflicts of interest.

\section{Authors contributions}

Conceptualization FY, KY, HF; Investigation KY; Methodology FY; Project administration FY; Supervision HF; Validation MM, NH; Writing FY.

\section{References}

1. Homepage of Japan Red Cross Association (in Japanese),

2. Homepage of Donated Blood Distribution Foundation (in Japanese).

3. Kato K, Ueno T, Okada M, et al. Effects of mechanical-shaking and long distance transportation on stored blood. J Jpn Society of Transfusion. 1959;5(6):287-230.

4. Manual for the Storage and Management of Blood Products. The Ministry of Health, Labour and Welfare of Japan, 2020.

5. Blood cold chain. Blood transfusion safety, WHO.

6. Sharley PH, Williams I, Hague S. Blood transportation for medical retrieval services. Air Med J. 2003;22(6):24-27.

7. Sawant RB, Jathar SK, Rajadhyaksha SB, et al. Red cell hemolysis during processing and storage. Asian J Transfus Sci. 2007;1(2):47-51.

8. Hardwick J. Blood storage and transportation. I.S.B.T. Sci S. 2008;3(2):177-196.

9. Klose T, Borchert HH, Pruss A, et al. Current concepts for quality assured long-distance transport of temperature-sensitive red blood cell concentrates. Vox Sang. 2010;99(1):44-53.

10. Temperature During Shipment-Products, vol. 21 CFR 600.15(a) and 21 CFR 640.11(a). US Government Printing Office, Washington, DC;2010.

11. Prince Th, editor. Standards for Blood Banks and Transfusion Services. $26^{\text {th }}$ edn. American Association of Blood Banks, Bethesda (MD); 2009.

12. Campbell Lee S, Shaz B, Arena R, et al. Red blood cell products: consideration of the discrepant temperature ranges permitted for storage versus transport. Transfusion. 2012;52(1):195-200. 
13. Code of federal regulations Title 21.

14. Joint United Kingdom(UK) blood transfusion and Tissue Transplantation Services Professional Advisory Committee, eighth edition 2013;6.11: Transportation of blood components. Guideline for Blood Transfusion Services in UK.

15. 6.11.3. Transport of components from Blood Establishments to hospital blood banks/users, Guidelines for the Blood Transfusion Services, Joint United Kingdom Blood Trans and Tissue Transplantation Services Professional Advisory Committee (JPAC).

16. Yamagata Prefecture Joint Committee on Blood Transfusion Therapy Report on the 2014 survey and research project on measures to appropriately use blood products.

17. Biological Agents Standard, Ministry of Health, Labour and Welfare Notification No. 192.

18. Stein C, Caetano E. Transportation of blood in a helicopter emergency medical service: the importance of specialised equipment. S Afr J Crit Care. 2016;32(2):62-63.

19. Amukele T, Ness PM, Tobian AA, et al. Drone transportation of blood products. Transfusion. 2017;57(3):582-588.

20. Amukele TK, Hernandez J, Snozek CLH, et al. Street J. Drone transport of chemistry and hematology samples over long distances. Am J Clin Pathol. 2017;148(5):427-435.

21. Glauser W. Blood-delivering drones saving lives in Africa and maybe soon in Canada. CMAJ. 2018;190(3):E88-E89.

22. Igarashi T, Fujita $H$, Asaka $H$, et al. Patient rescue and blood utilization in Ogasawara blood rotation system. Transfusion. 2018;58(3):788-794.
23. Tocchetti R, Jones D. ISBT Blood Transport Container Validation Guidelines.

24. Fujita H, Tojo Y, Mine T, et al. Temperature management of red blood cell solution transported by car for transfusion at home. Open J Blood Dis. 2020;10(2):37-40.

25. Yakushiji F, Yakushiji K, Murata M, et al. The quality of blood is not affected by drone transport: an evidential study of the unmanned aerial vehicle conveyance of transfusion material in Japan. Drones. 2020;4(1):4.

26. Okada E, Odawara M, Murakami B, et al. Experiment on transportation of red blood cell products for blood transfusion by unmanned aerial vehicle equipped with blood transport device. Jpn J Transfus Cell Ther 2020;66(1):1-2.

27. Yakushiji K, Yakushiji F, Fujita H. The quality of blood dropped from an unmanned aerial vehicle (Drone). Hematol Transfus Int J. 2020;8(2):3840.

28. Yakushiji K, Yokochi T, Fujita H, et al. Effect of passenger airplane transport on blood. Hematol Transfus Int J. 2020;8(5):108-9.

29. Metcalf RA, Baker SA, Goodnough LT, et al. Transportation cooler interventions reduce plasma and RBC product wastage. Am J Clin Pathol. 2016;146(1):18-24.

30. Sakai M, Tsukahara A, Kuboi Y, Sato T, Sakaguchi T, Okamoto N. Challenges and future prospects in reducing blood waste: A report on a questionnaire survey on the use of blood products (Japanese).

31. Ramirez-Arcos S, Mastronardi C, Perkins H, et al. Evaluating the 4-hour and 30-minute rules: effects of room temperature exposure on red blood cell quality and bacterial growth. Transfusion. 2013;53(4):851-859. 